\title{
NEED ANALYSIS: THE WRITING SKILL INSTRUCTIONAL MATERIAL CONTEXT FOR ACADEMIC PURPOSES
}

\author{
Audi Yundayani \\ English Education Department,Sekolah Tinggi Keguruan Ilmu Pendidikan Kusuma Negara, Jakarta, \\ Indonesia \\ E-mail: audi_yundayani@ stkipkusumanegara.ac.id
}

Emzir

Language Education, Postgraduate of Universitas Negeri Jakarta, Indonesia

E-mail: emzir.unj@unj.ac.id

\author{
Zainal Rafli \\ Language Education, Postgraduate of Universitas Negeri Jakarta, Indonesia \\ E-mail: zainal.rafli@unj.ac.id
}

\begin{abstract}
APA Citation: Yundayani, A., Emzir, \& Rafli, Z. (2017). Need analysis: The writing skill instructional material context for academic purposes. English Review: Journal of English Education, 6(1), 59-70. DOI: 10.25134/erjee.v6i1.771.
\end{abstract}

\begin{abstract}
The required instructional material should be designed based on students' needs. This study is intended toidentify 1) material design and organization,2)language content, and 3) method and techniqueof the writing skill instructional material context for academic purposes which appropriate with students'characteristics and their situationrelated to the need of writing skills for academic purposes at non-English education study programs of STKIP Kusuma Negara Jakarta. The descriptive survey was used in identifying its' material context through questionnaire, semi-structured interview and non-participant observation. The respondents were non-English education study programs students duringthe fifth semester in academicyear of 2016-2017.The result showed that 1) It is required to have clear and easily understandable writing instructional material for academic purposes; 2) The required language content is related to a)rhetorical-functional (descriptive, narrative, classifying and identifying); b) academic genres, in the forms of essay and report; c)writing process; d) summarizing; e) paraphrasing; 3) The method and techniques which are applied to instructional material must empower thestudents to practice a lot through communicative and applicative activities. Based on the findings, it can be concluded that need analysis should be the starting point in designing the instructional material, due to it is a process to determine students' needs according to their wants, lacks, and necessities.
\end{abstract}

Keywords: need analysis, writing for academic purposes, instructional material context

\section{INTRODUCTION}

Need analysis required as the main driving factor to design the whole component of teaching and learning process, including the instructional material. The area of need analysis covers present situation analysis, target situation analysis, and learning context analysis. Learning context analysis involves some consideration to the teachersconcerning with the methods, the materials, the facilities and the connection of the course implementation with the students' background and learning goals.
Need analysis is the cornerstone of ESP that leads to a very focused course (DudleyEvans \& St. John, 1998). It can be seen as a process to assess students' communicative needs in order to achieve specific learning objective. The aim of need analysis is to collect the information concerning students in order to define the target situation and environment of studying ESP (Otilia, 2015). As the instrument to establish how and what the learning process will be held, need analysis covers many aspects of teaching and learning 
process including students' background, students' current language

proficiency,students' purpose in learning English, etc.

The first step in designing language course is the need analysis implementation that covers: 1) the target situation analysis which informs the objective and productoriented needs, also the skills and language required for the context in which students will use the English; 2) the learning situation which provides information about subjective needs; 3) the means analysis which provides information about the educational contexts (Benavent \& Sánchez-Reyes, 2015). This statement emphasises Hyland's view concerning with a framework for need analysis which is divided into 1) present situation analysis that concerns with students' current condition or backgrounds, including the objective data (age, previous learning experience, etc) and subjective data (students' weaknesses, strengths, etc); and 2) target situation analysis that focuses on students' roles, skills and knowledge (Hyland, 2006). A portray of the learning goals will be formed by the result of need analysis and it will require teacher's belief, value, and philosophies of teaching. By the end, they will develop the whole component of learning and teaching process properly.

Barnard and Zemach in Tomlinson said that one of English teaching areas is English for Specific Purposes (ESP) that can be seen as the selection of teaching content and approach according to perceived needs of the students (Tomlinson, 2003). ESP is focused on English teaching and learning process related to the particular job or study-related cause. English for Academic Purposes (EAP), as a branch of ESP, provides students with proper English skills that are required in a tertiarylevel study or college level, including the way of presenting, researching, and publishing in academic field. The key element in all communication including in writing for academic purposes is knowing and understanding about the genre. It involves the understanding of the expectations of the discourse community that reads the text and of the conventions related with structure, the language and the rhetoric of the genre (Dudley-Evans \& St John, 1998).

EAP required to complete academic demands, one of them is writing for academic purposes. It occupies some approaches applied: 1) product approach; 2) process approach; and 3) summarising, paraphrasing and synthesizing. Product approach provides a model and various exercises. It is divided into 1) rhetorical-functional covers language functions; the main ones are description (including processes and sequencing), narrative, instruction, explanation, definition, exemplification, classification, comparison and contrast, cause and effect, expressing, generalisation and specificity, discussion and argumentation (problem and solution), drawing conclusions; 2) academic genres include essays, reports, case studies, projects, literature reviews, exam answers, research papers/articles, dissertations, and theses. Jordan stresses that academic discourse genres and the range and nature of academic writing tasks aimed at supporting students to socialize into the academic context. Process approach emphasizes in composing processes in writing through the recursive cycle. It means that the students will plan, draft, and edit but then it will be required re-plan, re-draft, and re-edit. Summarising, paraphrasing and synthesizing are important aspects of academic writingrequired in the field of academic purposes. They relate to academic reading by providing meaningful insights of how students present their reading result from the source text to writing (Jordan, 1997).

The concept of writing approaches is clearly in the term of product approach, process approach, including summarising, paraphrasing and synthesizing. It can be concluded that writing for academic purposes is often seen as the process of thinking, constructing and revising, including developing the concept. In doing it, students must realize that they will need several efforts, from drafting, correcting, and amendingthe text continuously until the writing product is proper.

In the area of English Academic Purposes, the students' competence in writing for academic purposes required in the college 
level learning process. It is seen not just as a standardized system of communication but also as an essential tool for students in constructing new knowledge. It also can be seen as a means to know students' competency, students' personal interest, and academic performance. Moreover, writing can be seen as the result of thinking, concept development, and revision. It requires special skills to explore writers' ideas to be presented and to be understood.

Writing for academic purposes is different from writing skill at high school level. It often causes students get difficulties in practicing it. Some studies showed the inadequacy of writing skill for academic purposes in university level, including the expectations of applying it. Most of the problems appear due to students' failure to understand the difference of learning goal between high school and university which initiate students into the scope of writing skill for academic purposes (Ivanic \& Lea, 2006; Lilis \& Scott, 2007). Concerning that statement, many factors of learning components must be applied based on the students' requirement in achieving the expected goal related to writing for academic purposes.

The material can be anything that used to assist English learning process. It can be the instructional, experiential, or exploratory as long as it can inform the students about the language use, provide the experience of the language in use, stimulate language use and support the students to discover the language based on their needs (Tomlinson, 2003). In deciding the suitable material, teachers' creativity and understanding to the students' needs are the most important aspect. The chosen material used to ease students' understanding of the learning content and context. Cunningsworth states that in the scope of English language teaching, the instructional material should have multiple roles: 1) a resource for presentation materials (spoken and written). It can give the information concerning the presented materials; 2) a source of activities for student practice and communicative interaction. It should guide the students to practice the language using; 3) a reference source for students on grammar, vocabulary, pronunciation, etc. The instructional material must give the information about language component; 4) a source of stimulation and ideas for classroom language activities. Not only as the knowledge source, the instructional material must stimulate the students by providing suitable information and presenting some learning activities to strengthen students' comprehension of language use; 5) a syllabus (where they reflect learning objectives which have already been determined). It can be the reference how to carry out the English learning process; 6) a resource for selfdirected learning or self-access work. The instructional material should be a source for students to be able to study independently, so it is important to ensure that the information and the instruction presented is quite clear; 7) a support for less experienced teachers who have yet to gain in confidence. Not only for students, the instructional material also can be as a support for teachers and lecturers to know what and how should be taught (Cunningsworth, 1995, p. 6).

In the area of ESP, Dudley-Evans and St. John (1998) suggest that the materials have some functions: 1) as a source of language. Due to English as a foreign language that studied, it requires a means that can be as a source in learning English; 2) as a learning support. The instructional material should help the learning process by giving the information, guidance in order to enhance students comprehension; 3) for motivation and stimulation. The instructional material should motivate and stimulate the students through its content and context. Good material can encourage students to learn through: 1) its interesting texts; 2) enjoyable activities which engage the students' thinking capacities; 3 ) opportunities for students to use their existing knowledge and skills; and 4) content which both students and lecturers can cope this (Hutchinson \& Waters, 1987, p. 107).

Instructional material context involves consideration of some criteria: 1) aims and approach. It relates to a degree of correspondence to the students' needs; 2) bibliographic features. It shows the quality and availability of the package; 3 ) design. It shows 
the attractiveness of the layout, visual appeal, readability and instructions clarity; 4) organization. This relates to sequencing and progression of suitable exercises, units, and proficiency level; 5) content. It shows a degree of authenticity, relevance, and appropriacy of the text genres; 6) methodology. It will extend to which tasks, exercises, and methods which are appropriate to students' proficiencies and goals; 7) usability. This relates to flexibility, completeness, and feasibility of the materials; and 8) overall. It relates to the general quality of the text and its suitability for the purpose (Hyland, 2003, p. 98). The context of the instructional material can be a consideration in determining the suitability between its role, orientation, and students' needs.

The instructional material of writing skills for academic purposes should be tailored based on students' needs and learning objectives. In selecting the instructional material of writing skills for academic purposes, there are some requirements that should be considered; 1) the topic should make the students interested, culturally acceptable, and in line with the learning objectives; 2) the expected type of writing; 3 ) methods of generating ideas, whether through brainstorming, freewriting, listing, mapping, outlining which are appropriate for the students; 4) instruction for writing that will help the students to organize various types of writing, such as letters, description, narration, exposition, arguments and what students need to be practiced; 5) opportunities to collaborate in writing; 6) opportunities to revise which encourage students to do the various stages in writing process; 7) instruction in editing and proofreading. What students learn concerning with finding and editing their errors in writing (Richards \& Renandya, 2003, pp. 311-312). Instructional material plays a very special role in constructing students' knowledge and understanding by providing much access to specialized knowledge and skills. It can be a source to help the students to construct the mental representation, including writing skill for academic purposes.

Based on the observation at non-English education study programs of STKIP Kusuma Negara Jakarta, it was found that the writing skill instructional materials for the academic purposes have not been designed and developed based on students' needs. Need analysis have not been implemented. It causes students having low performance in writing skill for academic purposes. Most of them didn't have any motivation to be involved and to be active in class since they did not understand the essence of presented materials. The writing skills of the students are alarmingly weak and substandard. The majority problem is due toincompetence in syntax, coherence,idea expansion, content selection, topic sentence, rhetorical conventions, mechanics, organization, lack of vocabulary, inappropriate use of vocabulary (Fareed, Ashraf, \& Bilal,2016). That condition can be solved through the suitable instructional material use as one of the learning sources.

This current studyexplores students' perceptions and examine their opinions concerning with required writing skills instructional material' context for academic purposes. It will bring the basicinformation as further inquiry and suitable solution in developing instructional material, especially in writing skills for academic purposes.

\section{METHOD}

The study aims to determine students' need related to writing skill instructional materials' context for academic purposes. This descriptive research involved the fifthsemester students of non-English education study programs at STKIP Kusuma Negara Jakarta. 100 non-English education study programs students participated in demanding their perception concerning the writing skill instructional materials' context for academic purposes. The purposive sampling method was used to determine the respondents. The data were collected throughnon-participant observation, questionnaire survey, and semistructured interviews.

The researcher observed the students in the English class to know the real condition of English learning process, including the students' performance and the use of previous writing skill instructional material for academic purposes. The questionnaire used to 
know students' perceptionrelated to writing skill instructional materials' context for academic purposes. The data obtained from the questionnaire were analyzed then summarize in the table form. In addition, the semi-structured interview was applied to get deeper information from students' conceptions of instructional material context. The interviews with the students were done after questionnaire. The interviews were applied to find the problem more openly by asking for opinions and ideas from respondents.

The data were analyzed quantitatively and qualitatively. It is quantitative in terms ofdisplayingquestionnaire's result. Meanwhile, it is quantitative in dealing with the collected data reduction, data display, and conclusion. Qualitative data analysis is an interpretive process, researcher reflect on their personal viewpoints and how they shape their interpretations of the data (Clark \& Creswell, 2015, p. 364).

\section{RESULTS AND DISCUSSION}

Need analysis of learning material context is a process to find students' expectations and needs by identifying the effective way of instructional material context to be presented. The series of learning needs to be prepared and adapted should be based on the characteristics of studentswhichwere summarized and arranged to achieve the objectives of certainlyexpected competencies.
This step can be seen as a process to identify the needs of instructional materials related to writing skill for academic purposes in accordance with the studentscharacteristics, background, and their environmental setting. The indicators of instructional material context analysiscovered, (1) Design and organization; (2) Language content; and (3) Method and techniques applied in instructional material.

\section{Design and organization}

Students' comprehension of the material will be determined by the instructional design and organization. Students should feel ease in using the instructional material, in other words, the instructional material must be presented according to the students' requirement. The structure, function, skill presented based on its' complexity, needs, objectives, difficulties, and usability are the important aspectsof designing and organizing the instructional materials.

The design and organization of writing skill materials for academic purposes should be easy to be understood by the students. It should give clear guidance and progressive reinforcement, so the students will have selfconfidence to study the given instructional material personally. Students' perceptions based on their needs should be the basis to design and organize the instructional material.

Table1. Students' perceptions of design and organization applied in instructional material

\begin{tabular}{clcc}
\hline No & \multicolumn{1}{c}{ Indicators } & $\begin{array}{c}\text { Percentage of } \\
\text { needs }\end{array}$ & Demand \\
\hline Design and organization & $87 \%$ & Needed \\
\hline 1 & $\begin{array}{l}\text { Instructional materials composition of writing for academic } \\
\text { purposes based on the structure, function, topic and skills } \\
\text { aspects in accordance with the needs of students. }\end{array}$ & $80 \%$ & Needed \\
\hline 2 & $\begin{array}{l}\text { Instructional materials composition of writing for academic } \\
\text { purposes based on the order of complexity, needs, } \\
\text { objectives, difficulties, functions and usability. }\end{array}$ & $87 \%$ & Needed \\
\hline 3 & $\begin{array}{l}\text { The display of instructional materials to writing for } \\
\text { academic purposes should be clear and easy to understand. }\end{array}$ & $80 \%$ & Needed \\
\hline 4 & $\begin{array}{l}\text { Instructional materials of writing for academic purposes } \\
\text { should provide various exercises and tasks. }\end{array}$ & $87 \%$ & Needed \\
\hline 5 & $\begin{array}{l}\text { Many template of English writing for academic purposes is } \\
\text { required. }\end{array}$ & $86 \%$ & Needed \\
\hline 6 & $\begin{array}{l}\text { Evaluation of instructional materials of writing for academic } \\
\text { purposes should be done periodically. }\end{array}$ & $85 \%$ & Needed \\
\hline 7 & $\begin{array}{l}\text { Clear guidance of instructional materials of writing for } \\
\text { academic purposes is required, so students can learn }\end{array}$ & & \\
\hline
\end{tabular}


independently.

The table shows that the whole components of the instructional materials'design and organization should be organized according to the structure, function, topic and skill aspects required by the students based on the order of complexity, needs, objectives, difficulties, functions, and uses. The questionnaire result was strengthened by the interview results. The interview results showed that the students also need instructional materials thatprovide English language writing models for academic purposes that can be used as examples, as well as various exercises and assignments to support the students' mastery in writing skill for academic purposes. Clear guidance in instructional materials of writing for academic purposes is also required by students as a guidence for autonomous learning, including the need for the instructional materials evaluation.

It is important to confirm that the instructional material design and organization of writing for academic purposes should be systematic and student-friendly. The composition of the instructional material should be in line with students' needs. The way in designing and organizing the instructional material gives impact to students' understanding and motivation in learning. As a learning aid, it is important to make sure that the designed instructional material can support teaching and learning process. All of the units and exercises should be well linked in terms of theme, situation, function, and topic of writing for academic purposes development, including the order of complexity, needs, objectives, difficulties, and usability of the instructional material.

As a productive skill, writing must be practiced a lot. Students should be motivated to rehearse through the instructional material. To achieve the ability in writing for academic purposes, students require clear, easy and various exercises and taskswhich can make them develop their performance. Exercises and tasks are ways to explore students' learning experiences and their achievement in writing skills. To enhance the learning goal, the instructional material should provide many templates of English writing for academic purposes.In writing, many given templates in instructional material required toportray students' attention to its important features, then they are required to produce a similar or parallel text.

Instructional materials evaluation of writing for academic purposes should be done periodically.It is required by the students in order to measure the suitability of the instructional material with the students' needs. The things that must be evaluated cover many thingssuch as, the instructional material capability to motivate the students, the impact of the instructional materials, the practicality and clarity of the instructional material, etc.

The description above shows us how instructional material should be designed and organized based on the students' perception. Design and organization of the instructional material can be seen as the important performance to attract students' attention in using the instructional material. By providing clear guidance, good composition, and proper display, the instructional material of writing for academic purposes should be as a source to increase students' knowledge and skills in order to achieve the learning goals.

\section{Language content}

Language content in writing skill instructional material for academic purposes concerns with what is being taught. It should be compared with what the students' need to learn and expect to learn based on their lack, want and necessities in the area of writing for academic purposes. Students should realize the relevant and benefit of instructional material content. The students will be motivated in learning when the content of the instructional material related to their interests and their need to perform in the academic field. Teachers should notice the impact of given instructional material, especially the language content. It is important to assign the language content that will develop students' curiosity, interest, and attention in learning. So by the end, the students' competency will increase. 
In the area of writing for academic purposes, the content of instructional material can be the product appoach in term of rhetorical-functional and academic genres, the process approach that will view writing as a creative process, including summarising and paraphrasing. All of the content in the instructional material should be in line with the academic field.

Table 2. Students' perceptions of language content assigned in instructional material

\begin{tabular}{|c|c|c|c|}
\hline \multirow{2}{*}{\multicolumn{4}{|c|}{$\begin{array}{l}\text { No } \\
\text { Language content }\end{array}$}} \\
\hline & & & \\
\hline 1 & $\begin{array}{l}\text { The integration of instructional materials of writing for } \\
\text { academic purposes with other language skills in accordance } \\
\text { with the learning objectives. }\end{array}$ & $81 \%$ & Needed \\
\hline 2 & $\begin{array}{l}\text { Writing process materials in terms of: 1) exploring ideas; 2) } \\
\text { prewriting; 3) organizing; 3) writing first draft; 4) revising; } \\
\text { 5) producing the final copy; 6) editing; 7) proofreading. }\end{array}$ & $86 \%$ & Needed \\
\hline 3 & Academic genres materials & $83 \%$ & Needed \\
\hline & 1) Essays & $82 \%$ & Needed \\
\hline & 2) Reports & $80 \%$ & Needed \\
\hline & 3) Case studies & $50 \%$ & Not yet needed \\
\hline & 4) Projects & $63 \%$ & Not yet needed \\
\hline & 5) Literature reviews & $42 \%$ & Not yet needed \\
\hline & 6) Exam answers & $46 \%$ & Not yet needed \\
\hline & 7) Research papers/articles & $46 \%$ & Not yet needed \\
\hline & 8) Skripsi/Theses & $44 \%$ & Not yet needed \\
\hline 4 & Rhetorical-functional materials & $81 \%$ & Needed \\
\hline & 1) Description & $82 \%$ & Needed \\
\hline & 2) Narration & $83 \%$ & Needed \\
\hline & 3) Instruction & $58 \%$ & Not yet needed \\
\hline & 4) Explanation & $65 \%$ & Not yet needed \\
\hline & 5) Definition & $82 \%$ & Needed \\
\hline & 6) Exemplification & $46 \%$ & Not yet needed \\
\hline & 7) Classification & $82 \%$ & Needed \\
\hline & 8) Comparison and contrast & $59 \%$ & Not yet needed \\
\hline & 9) Cause and effect & $59 \%$ & Not yet needed \\
\hline & $\begin{array}{l}\text { 10) Expressing: purpose, means, prediction, expectancy, } \\
\text { reservation, result }\end{array}$ & $40 \%$ & Not yet needed \\
\hline & 11) Generalisation and specificity & $40 \%$ & Not yet needed \\
\hline & 12) Discussion and argumentation (problem and solution) & $57 \%$ & Not yet needed \\
\hline & 13) Drawing conclusions & $48 \%$ & Not yet needed \\
\hline 5 & $\begin{array}{l}\text { Materials related to applying quotation, footnotes and } \\
\text { bibliography }\end{array}$ & $68 \%$ & Not yet needed \\
\hline 6 & Materials related to finding and analysing data & $63 \%$ & Not yet needed \\
\hline
\end{tabular}

The previous topics are the essence derived from the entire teaching materials related to writing skills for academic purposes. Meanwhile, through the questionnaire and interviews, the researchers also seek the information concerning with the most required language content that should be assigned tothe instructional material. The result of students perceptions shows the most required language content that must be covered in the instructional material by minimum $80 \%$, the percentage of the students' needs. Less than $80 \%$ means students have not needed them in this short time according to the learning goal in the academic field.

The students need instructional materials of writing for academic purposes that are integrated with other language skills.Writing for academic purposes requires input that can be from much varieties of the reading text since it can give the positive impact for students in constructing and composing the written information. Writing is the process of constructing any information and knowledge, including concept development. By integrating writing skills with other language skills in the 
instructional material, it can give comprehensive stimulus to develop students' ability in writing. The combination of receptive and productive skills in the instructional material provide rich and varied input and stimulus in order to facilitate students' proficiency in writing foracademic purposes.

Students require writing skills for academic purposes that include writing skills with a product and process approach. For writing skills with a product approach, itshould be focused on the academic genrethat includes essay writing and reports, while for rhetorical-functional, itshould be focused on descriptive, narrative, definition and classification skills. For writing skills with a process approach, the given material related to the stages of the writing process from exploring ideas, prewriting, organizing, writing the first draft, revising the draft, producing the final copy, editing, and proofreading.

Product approach in writing concerns with the products. Many provided models draw attention to its important and required features as the template. Students practice through the provided template that describes how and what the students could write.The required genre based on students' perceptions shows the students' purposes in writing. They have certain goals and informationto be conveyed based on the learning requirement. On the other hand, process approach in writing as the mental process emphasizes on the process of composing which should be utilized by the students. It focuses on students-centredness by allowing them to express personally started from planning, drafting, rethinking, revising, etc. Through the process approach, students learn how to build writing strategies by following some phases to produce a clear, comprehensive and understandable text.

The result of the interview informed that students also require the ability to write summary and paraphrasing. In the area of academic purposes, ability in making summary and paraphrasing are the important aspects. Students should comprehend the given information and re-write it by using their own words, style and also structure. The most important aspect of summary and paraphrasing is the content or the message that should be delivered. It is amust for the writer and the reader having the same perception and understanding concerning the written information presented.

By the end, the language content should deliver the material in order to develop students' writing ability and applicative in the field of the academic context. It should be related to students' study skills in which one of them covers writing for academic purposes as the productive skill. Integrated language skills should strengthen the instructional material in order to stimulate students due to students' proficiency in writing for academic purposes. The product and process approach in writing are required by the students to be found in the instructional material of writing for academic purposes which covers; 1) some rhetorical-functional in the form of descriptive, narrative, explanation and definition, 2) academic genre in the form of essay and report, 3) writing process, 4) summary, and 5) paraphrasing.

\section{Method and technique}

Method and technique applied in the instructional material should give the opportunities for the students to practice a lot. It has to deliver the students toachieve communicative and applicative ability in writing for academic purposes. Implemented method and technique in the instructional material should expose the students to practice their writing skill in the authentic and real use. The applied method and technique can be seen as the stimulus to expose the students' writing ability for academic purposes.

Table 3. Students' perceptions of method and technique implemented in instructional material

\begin{tabular}{llcc}
\hline No & Indicators & $\begin{array}{c}\text { Percentage of } \\
\text { needs }\end{array}$ & Demand \\
\hline Methods and techniques & & & \\
\hline 1 & Question and answer & $87 \%$ & Needed \\
\hline 2 & Matching activity & $81 \%$ & Needed \\
\hline
\end{tabular}




\begin{tabular}{clcc}
\hline 3 & Communicating strategies & $82 \%$ & Needed \\
\hline 4 & Pictures and picture stories & $86 \%$ & Needed \\
\hline 5 & Puzzles and problems & $78 \%$ & Not yet needed \\
\hline 6 & Discussions and decisions & $86 \%$ & Needed \\
\hline 7 & Jigsaw & $67 \%$ & Not yet needed \\
\hline 8 & Information gap & $65 \%$ & Not yet needed \\
\hline 9 & Problem-solving & $87 \%$ & Needed \\
\hline 10 & Decision making & $85 \%$ & Needed \\
\hline 11 & Opinion exchange & $87 \%$ & Needed \\
\hline 12 & Taking notes & $76 \%$ & Not yet needed \\
\hline 13 & Concept mapping & $86 \%$ & Needed \\
\hline 14 & Inferencing & $86 \%$ & Needed \\
\hline 15 & Discriminating & $82 \%$ & Needed \\
\hline 16 & Diagramming & $71 \%$ & Not yet needed \\
\hline 17 & Co-operating & $87 \%$ & Needed \\
\hline 18 & Using context & $73 \%$ & Not yet needed \\
\hline 19 & Summarising & $81 \%$ & Needed \\
\hline 20 & Personalizing & $84 \%$ & Needed \\
\hline 21 & Self-evaluating & $86 \%$ & Needed \\
\hline 22 & Reflecting & $80 \%$ & Needed \\
\hline 23 & Brainstorming & $84 \%$ & Needed \\
\hline 24 & Mapping it out & $84 \%$ & Needed \\
\hline 25 & Reorganizing the information & $82 \%$ & Needed \\
\hline 26 & Completing documents & $73 \%$ & Not yet needed \\
\hline 27 & Previewing & $80 \%$ & Needed \\
\hline
\end{tabular}

$80 \%$ as the result of students' perception means that the presented method and technique required by the students to be applied in the instructional material of writing for academic purposes. Less than $80 \%$ means that the presented method and technique have not been needed by the students.

Related to the students' perception concerning with methods and techniques that should be implemented in instructional material, it was found that methods and techniques of presenting writing instructional materialsfor academic purposes required by students werefocused on assigning tasks or direct practice. In addition, students tended to require techniques that will make them interact with other students. Various techniques such as question and answer, discussions and decisions, problem-solving, decision making, opinion exchange, concept mapping, summarizing, using knowledge to learn something (inference), self-evaluating and brainstormingwere needed by students.

The finding shows that language learning is accepted more than a set of grammatical rules that should be understoodor many vocabularies that should be memorized by the students. They see the process of language learning as a dynamic process for creating meaning in practicing language skill including writing for academic purposes. Due to the students' expectation, the applied method and technique should be a process of habit formation through many activities, both in exercises and tasks. By the end, the students are not only to know what the writing for academic purposes is but also to know how to write for academic purposes. The various techniques applied in the instructional material were seen as a tool for communication rather than as a set of theoretical term.

Students require the opportunities to enhance their personal experience related to writing skill for academic purposes through the provided techniques applied in instructional material. Various and attractive techniques were seen as a way to link the language learning process and language use.As a learning source, the instructional material should give positive impact for the students in writing skill mastery for academic purposes. By the provided methods and techniques in instructional material, students realize that being mastery in writing skill for academic purposes requires active learning, many practices, emotional experiences, 
thinking process and communicative competence.

Applied methods and techniques in instructional material required by the students can be seen as a part of communicative exercise principle; the process of learning by doing. The required techniques focus on student-centered and the teacher's role should be the instructor, organizer, advisor, designer including the manager in the learning process. The required methods and techniques should be authenticity and also problem-solving. By the end, the students' need and their learning goal in writing for academic purposes will be fulfilled easily due to the design of the instructional material based on the result of need analysis as the basis.

Based on the results of the questionnaire and observations conducted by the researchers, there are some important findings related to students' perceptions concerning with instructional materials context of writing skill for academic purposes. Re-examining the literature provided in deciding the suitable material, teachers' understanding of the students' needs are the most important aspects. Related to that, instructional materials' design and organization should be organized according to the structure, function, topic and skills aspects required by students based on the order of complexity, needs, objectives, difficulties, functions, and uses.

The important thing concerning with the language content, students have perceptions that the content of instructional materials of writing for academic purposes should be integrated with other language skills. They need writing materials for academic purposes presented through product and process approach, including summarising and paraphrasing. The product approach should be focused on the academic genresthat includeessay writing and reports, while for rhetorical-functional;itshould be focused on descriptive, narrative, definition and classification skills. For writing skills with a process approach, the material given should be related to the stages of the writing process from exploring ideas, prewriting, organizing, writing the first draft, revising the draft, producing the final copy, editing, and proofreading. The finding in line with the multiple roles of instructional material in the scope of English language teaching. As the source and reference, the instructional material should give the information about the writing skills required by the students. In addition, it should stimulate and motivate the students. To obtain those, it is important to design the content of instructional material based on the students' needs.

Students' perception shows that the methods and techniques applied in the instructional material should give students the opportunities to practice a lot, in other words, it should be communicative and applicative based on student-centered learning approach. As the source of activities for students practice, the applied techniques should present some learning activities to strengthen students' comprehension in writing for academic purposes. Students prefer to use various techniques through communicative interaction. This finding in line with the material roles in which the instructional material should guide the students to practice the language use and to be a source of stimulation and ideas for classroom language activities. By the end, methods and techniques applied in the instructional material of writing skill for academic purposes should be various, attractive, applicative and focus on communicative interaction based on students' need so that it will give the positive impact in enhancing students' motivation, performance, and competency in writing skill for academic purposes.

\section{CONCLUSION}

In conclusion, writing proficiency for academic purposes should be mastered by undergraduate students. It is important to provide any learning components to enhance students' mastery in writing for academic purposes. One of them is instructional materials as the learningsource. The context of instructional materialsshould be developed based on the need analysis focused on studentcentered approach. The findingsinform the teachers or the curriculum designers to identify students' perspective by promoting their critical awareness in relationto 
instructional materials context, and it helps them to uplift their knowledge and skill in writing for academic purposes.

The context of instructional materials must be relevant to students' learning goal, especially in writing for academic purposes. By the end, it is a must to make sure that the designed instructional materials should be focused on communicative competence. Therefore, need analysis is the ground on which instructional materials can be developed in order to lead students' motivation and proficiency in writing skill for academic purposes.

\section{REFERENCES}

Benavent, G. T.,\& Sánchez-Reyes, S. (2015).Target situation as a key element for ESP (Law Enforcement) syllabus design. Procedia - Social and Behavioral Sciences, 173, 143 - 148. DOI: 10.1016/j.sbspro.2015.02.044

Clark, V. L. P.,\& Creswell, J. W. (2015). Understanding research: A consumer's guide(2nd $E d$.). NJ: Pearson Education, Inc.

Cunningsworth, A. (1995). Choosing your coursebook. Oxford: Macmillan Education.

Dudley-Evans, T.,\& St John, M. (1998). Developments in English for specific purposes. Cambridge: Cambridge University Press.
Fareed, M., Ashraf, A.,\& Bilal, M. (2016). ESL learners' writing skills: Problems, factors and suggestions.Journal ofEducation and Social Sciences, 4(2), 81 - 92. DOI: $10.20547 /$ jess0421604201.

Hutchinson, T., \&Waters, A. (1987).English for specific purposes: A learning-centered approach. New York: Cambridge University Press.

Hyland, K. (2003). Second language writing. New York: Cambridge University Press.

Hyland, K. (2006). English for academic purposes. Oxon: Routledge.

Ivanic, R., \&Lea, M. R. (2006). New contexts, new challenges: The teaching of writing in UK higher education. In L. GanobcsikWilliams (ed.), Teaching academic writing in UK higher education: Theories, practice and models. London:Palgrave/MacMillan.

Jordan, R.R. (1997). English for Academic Purposes: A guide and resource book for teacher. Cambridge: Cambridge University Press.

Lilis, T., \& Scott, M. (2007). Defining academic literacies research: Issues of epistemology, ideology and strategy.Journal of Applied Linguistics, 4(1), 5-32.DOI: 10.1558/japl.v4i1.5

Otilia, S. M. (2015).Needs analysis in English for specific purposes. Annals of theConstantin BrâncuşiUniversity of Târgu Jiu, Economy Series, 1 (II).

Richards, J. C.,\& Renandya, W. A. (2003).Methodology in language teaching: An anthology of current practice.Cambridge: Cambridge University Press.

Tomlinson, B. (2003). Developing materials for language teaching. GB: Cromwell Press. 
Audi Yundayani, Emzir, \& Zainal Rafli

Need analysis: The writing skill instructional material context for academic purposes 